\title{
The Ambassador during the Vietnam War: Keith Waller, 1964-70
}

\section{Peter Edwards}

The tenure of Keith (from 1968, Sir Keith) Waller as Australian Ambassador in Washington was notable for three principal reasons, each of which had an element of paradox. The first arose from his being the first career diplomat to hold the position; the second concerned questions of access and influence; and the third revolved around his involvement with Australian-American diplomacy during the Vietnam War.

\section{The career appointee}

In 1964 Keith Waller was chosen as the first career diplomat to be appointed as Australian Ambassador in Washington. At the time, much was made of this development, which was greeted as a major breakthrough for the youthful diplomatic service. ${ }^{1}$ It certainly was a pioneering step, but it only happened by default. Waller recalled being told by the Minister for External Affairs, Sir Garfield Barwick, presumably in early 1964, that, having spoken with the Prime Minister, Sir Robert Menzies, Barwick was about to propose Waller for the embassy. Barwick later

1 See, for example, Alan Watt, 'Australia and the Ambassadorial Issue', Australian Quarterly, vol. 36, no. 4, December 1964, pp. 11-18. 
said that Waller turned 'as white as a sheet and then a bit green', and that it was the only time Barwick saw Waller lose his composure. Waller heard nothing more for some time, while the Canberra rumour-mill linked the names of several ministers, including Menzies himself, to the appointment. Then, soon after Paul Hasluck replaced Barwick in April 1964, Waller's appointment was confirmed. ${ }^{2}$

It was no secret that Menzies had wanted to appoint a Cabinet minister rather than a career diplomat, but had been frustrated by the absence of a suitable appointee. In his interview before departure, Menzies said to Waller: 'I'll tell you quite frankly that this is a position in which I would prefer to have a Cabinet Minister, but the ones I consider suitable I can't spare and the ones I can spare are not suitable.'

In fact, Menzies evidently appraised even ministers he did not consider very suitable. According to Barwick's memoirs (which are not always totally reliable on detail), Menzies asked him if he had considered offering the post to John Gorton. Barwick said that he had rejected the idea, because Gorton had shown, as Assistant Minister for External Affairs, that he was inclined to 'freelance'. He would have to insist that Gorton adhered to the policies laid down by the government and the minister, and Gorton would probably rebel against any such instruction. Menzies told Barwick that he could offer the post to Gorton, safe in the knowledge that he would refuse - not because he would object to strict instructions not to 'freelance', but because he wanted to keep open the possibility of becoming prime minister. Menzies clearly thought this unduly ambitious. Gorton's promotion under Menzies had been much slower than others who had been elected to parliament in 1949. In 1964 he was still in the outer ministry - his promotion to Cabinet only came when Harold Holt succeeded Menzies in 1966. Barwick made the offer, and Gorton rejected it, just as Menzies had predicted. ${ }^{4}$ Gorton's estimate of his prospects proved more accurate than Menzies'. By January 1968

2 Keith Waller, A Diplomatic Life: Some Memories, edited by Hugh Dunn, Australians in Asia Series no. 6, Centre for the Study of Australia-Asia Relations, Griffith University, 1990, p. 35. This monograph is based on the transcript of oral history interviews given by Waller to Professor John Donald Bruce Miller of The Australian National University, the transcripts of which are held in the National Library of Australia.

3 Waller, A Diplomatic Life, p. 35.

4 Garfield Barwick, A Radical Tory: Reflections and Recollections, Federation Press, Sydney, 1996, pp. 206-7. 
Menzies had retired, his successor Harold Holt had drowned, and Gorton had become prime minister, where he remained for the second half of Waller's term.

So how did Waller come to be the first career diplomat appointed to the Australian embassy, albeit by default? John Keith Waller, born in 1914, was one of the bright young men - there were very few women, in the days of the public service marriage bar - recruited to the newly revived Department of External Affairs in the late 1930s and early 1940s. ${ }^{5}$ The best of that cohort, including Arthur Tange, James Plimsoll, Patrick Shaw, Keith Shann, Laurence McIntyre, Tom Critchley and Ralph Harry, advanced quickly to senior positions in the 1950s, as the department and its overseas missions grew rapidly and without a generation of older officials ahead of them. Although his application to join External Affairs in 1935 was rejected, Waller transferred there within months of an appointment to the Prime Minister's Department. He rapidly earned a reputation as 'one of the few consummate Australian diplomatists our Foreign Service has known', ${ }^{6}$ renowned for his calm efficiency even under the most trying conditions.

His diplomatic skills were displayed as much in dealing with fellow Australians as with foreign interlocutors. He survived for a remarkably long time as private secretary to the notoriously irascible William Morris (Billy) Hughes. In 1943 he was sent to Chungking as Second Secretary to open Australia's first mission to China and then to support Sir Frederic Eggleston, the intellectually powerful but severely arthritic appointee, as head of mission. In 1945 Waller was appointed secretary to the Australian delegation to the San Francisco Conference at which the Charter of the United Nations Organization was drafted. The delegation was notoriously divided into two rival teams of officials and advisers. One, designated by Prime Minister John Curtin and led by the Deputy Prime Minister Frank Forde, had their offices and bedrooms mostly on the 11th floor of the Sir Francis Drake Hotel; the other, chosen and led by the hyperactive Minister for External Affairs, Herbert Vere Evatt,

5 See Peter Geoffrey Edwards, Prime Ministers and Diplomats: The Making of Australian Foreign Policy 1901-1949, Oxford University Press, Melbourne, 1983, chs 4 and 5.

6 'Editor's Note' (presumably Hugh Dunn), A Diplomatic Life, unnumbered page. 
had theirs on the 17th floor. Waller, with his office on the 11th floor and his bedroom on the 17th, proved an impartially efficient secretary, winning the confidence of all. ${ }^{7}$

The opinion of one member of the Evatt team would prove especially important in Waller's later career. Paul Hasluck, a temporary appointee to External Affairs, recorded his admiration for Waller's 'unruffled diplomatic finesse in making awkward situations turn out right. If ever Waller dropped a slice of toast, I feel sure that he could arrange that it would not fall with the buttered side down'. Hasluck was critical of many of the young diplomats in External Affairs, but he expressed great respect for Waller's political insight and wise counsel, which, as Hasluck noted pointedly, was delivered 'moderately and succinctly'.

\section{Access and influence}

As flagged earlier in this volume, one standard measure of an ambassador's success is their ability to identify the key policymakers in the host government and to gain the best possible access to, and thus influence on, them. In the complex and ever-changing interagency process that shapes policymaking in Washington, that is no easy matter, but crucially important. The paradox here is that Waller had something extraordinarily rare, hundreds of hours of personal contact with the President himself; and yet the circumstances were such that that this 'face time' did not translate into opportunities to exert any significant influence on American policy.

President Johnson in 1965 appointed Ed Clark as his ambassador in Canberra. Clark was often portrayed in the Australian media as something of a buffoon, a good ol' boy with a fondness for The Yellow Rose of Texas. In fact, as Robert Caro's multi-volume biography of Lyndon B Johnson makes clear, Clark was, from very early in Johnson's political career, an extremely important adviser, supporter and fundraiser. ${ }^{9}$ As Johnson's political fortunes deteriorated, he would summon Clark, who would have to make the arduous trip back to Washington so that

7 Edwards, Prime Ministers and Diplomats, pp. 162-9; Paul Hasluck, Diplomatic Witness: Australian Foreign Affairs 1941-1947, Melbourne University Press, Melbourne, 1980, chs 15, 18-20.

8 Hasluck, Diplomatic Witness, p. 203.

9 See, for example, Robert A Caro, The Years of Lyndon Johnson, vol. 2, Means of Ascent, Random House, New York, 1990, p. 102. 
Johnson could speak to him for a couple of hours. It became the custom for Keith and Alison Waller to accompany Clark. They thus got to know Johnson and his wife well. Waller saw that Johnson had a genuine, rather romantic, affection for Australia (which he had visited on leave from Congress during World War II), and a deep appreciation for Harold Holt. His reaction to Holt's death was deep and genuine, leading to his decision to attend the memorial service. But Waller concluded that Johnson was a difficult man to talk to, and that he never had a real conversation despite spending many hours in his company. ${ }^{10}$

For Waller, therefore, the significance of the access to Johnson was not the direct contact, but the ability to drop his name when dealing with people in Commerce or State causing difficulties over trade matters. In his own recollection:

One had to be very careful about how to exploit the Johnson euphoria for Australia ... But from time to time, when a difficult person in Commerce or in State was being tough and unreasonable about access for Australian products, one would shake one's head and say 'Well, I hope I don't have to take this to the White House'. And that would act like a charm. ${ }^{11}$

\section{Confrontation and Vietnam}

It would be natural to assume that Waller's term as Ambassador was dominated by the Vietnam War. His time in Washington, from August 1964 to March 1970, included the escalation of the American and Australian commitments, the peak years of the war, the Tet offensive of early 1968, increasingly strong protests against the war, Johnson's decision not to stand for re-election, the victory of Richard Nixon in the 1968 election, and the first withdrawals of American forces under the rubric of 'Vietnamisation'. These events, and the worldwide social and political turbulence associated with the late 1960s, certainly established the climate of his years in Washington; but that is not to say that he played a major role in shaping policy decisions. To explain this third paradox requires reference to his last departmental post before going to Washington.

10 Waller, A Diplomatic Life, p. 38.

11 Ibid., p. 39. 
From 1961 to 1963 Waller was first assistant secretary (at that time, before the creation of a deputy secretary, the level immediately below the head of department) in charge of the division responsible for policy towards Southeast Asia, then the most critical area of Australian foreign policy. In that role, Waller played a major role in policymaking towards 'Konfrontasi', Indonesia's Confrontation of the new federation of Malaysia. Australia opposed Indonesia's stance, but handled the crisis with a skilful and nuanced display of statecraft that Garry Woodard has christened, with understandable pride, 'best practice' in diplomacy. ${ }^{12}$ Notwithstanding pressure from across the political spectrum to adopt a stronger military stance, the Australian Government exercised vigorous and independent diplomacy, especially in regional capitals, combined with effective but restrained military actions, shaping and executing a policy designed to allow Malaysia to come into being, but handled with caution in order to minimise damage to long-term relationships with Indonesia and other regional neighbours.

The policy was based on Australian interests and, as the diplomats liked to say, 'refined but not defined'by alliance considerations. But Australian policy was based on close association with both Britain and the US in Southeast Asia. There was no US section within the Department of External Affairs, so Waller was at the heart of Australia's relationship with the US.

External Affairs had a major influence on the policy on Confrontation. The principal policymakers were Barwick as Minister, Tange as departmental Secretary, Waller as division head, and Gordon Jockel as head of the Indonesia-Malaysia desk, together with two highly effective heads of mission, Keith Shann in Jakarta and Tom Critchley in Kuala Lumpur. The Confrontation policy was central to the confidence of the diplomats that, under Barwick, they formed a very effective team. Good personal relations between minister and officials helped - Barwick even borrowed Waller's dinner jacket on occasions. But this relationship did not continue when Hasluck succeeded Barwick in April 1964. Hasluck's relations with departmental officials were generally frosty or worse. Some of the diplomats saw Hasluck as uncommunicative, withdrawn,

12 Garry Woodard, 'Best Practice in Australian Foreign Policy: "Konfrontasi” (1963-66)', Australian Journal of Political Science, vol. 33, no. 1, March 1998, pp. 83-93. See also Peter Edwards (with Gregory Pemberton), Crises and Commitments: The Politics and Diplomacy of Australia's Involvement in Southeast Asian Conflicts 1948-1965, Allen \& Unwin in association with the Australian War Memorial, Sydney, 1992, chs 14-17. 
and excessively dependent on Menzies; while he regarded them as excessively self-confident and misguided on relations with the US and Southeast Asia. ${ }^{13}$ But, as already noted, Hasluck exempted Waller from this critique. A mark of his skill was his ability to retain the confidence of both Hasluck and his departmental colleagues; he was fortunate to be in Washington in the later 1960s, well away from the intradepartmental tensions in Canberra.

Between 1961 and 1964, the department's success in shaping policy towards Confrontation was not emulated in the other developing crisis in Southeast Asia: the growing insurgency in South Vietnam. There is some evidence that the department sought to encourage a similarly restrained policy there, but in this case Menzies dominated policymaking, with the support of a small group of senior ministers including the Deputy Prime Minister, John McEwen. ${ }^{14}$ They sought Washington's assurance that American support could be expected if Indonesia escalated its Confrontation of Malaysia, perhaps taking action across the almost indefensible border between Indonesia's West New Guinea and the Australian-administered territories on the eastern half of the island. American reluctance to give any such assurance was obvious; moreover, it was linked to Australian support for the American role in Vietnam. The Australian Government was faced with a huge dilemma. It sought to keep both 'great and powerful friends', the UK and the US, engaged in Southeast Asia, but the British saw Indonesian expansionism as the major threat while seeking to stay out of Vietnam, while the Americans regarded Vietnam as the critical theatre and urged restraint in dealing with Indonesia.

Waller later claimed that he had major reservations about involvement in Vietnam from the outset, including opposing the commitment of the Australian Army Training Team in 1962. ${ }^{15}$ This occurred while Waller was still Ambassador in Moscow, but it is consistent with Barwick's initial comment to reporters, after the idea of Australian advisers had been raised in talks with the Americans, that Australia might send 'a handful', perhaps 'three or four men', in non-combat roles. A couple

13 Peter Edwards, Arthur Tange: Last of the Mandarins, Allen \& Unwin, Sydney, 2006, chs 7-8.

14 See Garry Woodard, Asian Alternatives: Australia's Vietnam Decision and Lessons on Going to War, Melbourne University Press, Melbourne, 2004; Edwards, Crises and Commitments, chs 16, 18; Peter Edwards, Australia and the Vietnam War, NewSouth Publishing, Sydney, 2014, chs 4, 5.

15 Waller, A Diplomatic Life, pp. 36-7. 
of weeks later, after further discussions with the Americans, Cabinet decided to send a team of 30 advisers. (The Training Team in later years was augmented to 83 , then 100 , and eventually 200 .)

Whatever his reservations, Waller seems to have kept them largely to himself when, as ambassador-designate to Washington, he accompanied Hasluck on a tour of Southeast Asia in June 1964. This was an important stage in the development of Australian policy, for Hasluck formed the view that the situation in Vietnam and Laos was more critical and dangerous than Confrontation, reversing the priorities of most Australians at the time. ${ }^{16}$

Waller's role in Washington, especially in the first two years, was largely an extension of his former role in Canberra. At this time the principal channel of diplomatic communications between Canberra and Washington ran from Hasluck through Waller to William Bundy, the Assistant Secretary of State for Far Eastern Affairs, and Secretary of State Dean Rusk. All four were experienced practitioners, with a good deal of mutual confidence. ${ }^{17}$ But this is not to say that the four men had a great deal of impact in shaping policy decisions. Policy on Vietnam, in both Washington and Canberra, was made by the heads of government and their closest advisers. For the most part, Waller and Bundy were conduits, conveying the views of their political masters rather than shaping them significantly. Even Hasluck and Rusk were not always central to their respective government's major decisions. Waller thought that William Bundy was not a great Assistant Secretary, and that his successor in the State Department, Marshall Green, had little influence. He had some success in developing contact with Johnson's national security advisers, McGeorge Bundy (William Bundy's more influential brother) and Walt Rostow. ${ }^{18}$

Within his first weeks in Washington, Waller was reporting American concerns that Britain might be pursuing an unduly provocative policy towards Indonesia. American policymakers also made it clear that Australia should be cautious in its military support for British policy in Confrontation. The Australians were put on notice that Washington would not 'bail us out' in the event of an escalated conflict with

16 Edwards, Crises and Commitments, pp. 300-1.

17 Ibid., p. 285.

18 Waller, A Diplomatic Life, p. 39. 
Indonesia. ${ }^{19}$ This was the start of a recurring theme of Waller's tenure. Australian ministers constantly sought reassurance of American support under the Australia, New Zealand, United States Security Treaty, either in general terms or with particular reference to Indonesia (at least until Confrontation was declared over in 1966).

Another theme was the constant pressure from the US for Australia to increase its own military capacity and to contribute significantly to the joint effort in Southeast Asia, especially in Indochina. Under the Kennedy and Johnson administrations, well before Richard Nixon enunciated what became known as 'the Guam doctrine' or 'the Nixon doctrine', American policymakers clearly indicated that they expected their allies to share more of the military burden. Washington was becoming weary of allies who seemed willing to "fight to the last American'. The Menzies Government was well aware of this view, and its importance in any decision about American commitments to Vietnam and elsewhere in the region. Waller was able to report in November 1964 that Rusk expressed particular pleasure over the Menzies Government's introduction of a selective system of conscription, which would produce a greater number of combat-ready forces. ${ }^{20}$

In the period from late 1964 to mid-1965, Australians were concerned both about a critical stage in Confrontation and the worldwide speculation over the future of American policy in Vietnam. It was increasingly likely that South Vietnam would fall to the communist insurgency unless the US and its allies intervened with massive force. In Washington, 'hawks' and 'doves' argued for or against American intervention.

In December 1964 McGeorge Bundy briefed Waller and his New Zealand counterpart, George Laking, on the Johnson Administration's decisions to escalate the war. The principal measure was an increase in the bombing campaign over North Vietnam, but Bundy referred to the possibility of committing US Marines, together with 'such ground forces as Australia and New Zealand might be able to provide'. When Waller sought clarification, Bundy suggested a further 200 advisers (in addition to the 83 already serving with the Training Team). ${ }^{21}$

19 Edwards, Crises and Commitments, p. 319.

20 Ibid., p. 329.

21 Ibid., pp. 336-7. 
In the following months Waller, on instructions from Canberra, repeatedly pressed for more information on American intentions and proposed strategy. It was clear that there was no clear political or military strategy, and that debate was intense within the interagency process' in Washington. Waller was the channel through whom Menzies and his senior ministers sided with the hawks, giving every possible encouragement to Johnson to stand firm, to commit American forces, and not to enter the negotiations proposed by the British Government and many others around the world. For example, it was through Waller that Menzies sent Johnson the text of his robust defence of American policy in Vietnam, in response to a group of Anglican bishops who had challenged its wisdom. ${ }^{22}$

When a crucial meeting on military strategy was held in Honolulu in late March, Australia was represented by the Chairman of the Chiefs of Staff Committee, Air Chief Marshal Sir Frederick Scherger, without any adviser from either the embassy in Washington or External Affairs in Canberra. At this time the Australians effectively pressed a battalion on to the Americans, even though American military strategy was still unclear and the Americans had not asked for such a commitment. After delays prompted by the need to secure a formal request from the South Vietnamese Government, Waller conveyed the formal offer of the Australian battalion to Rusk on 13 April. ${ }^{23}$

In subsequent years, Waller was a witness to the positive and negative manifestations of the Australian-American relationship, amid the tensions raised by the increasingly unpopular war. The relationship between governments was increasingly focused on the personal meetings between heads of government.

Waller was present when Harold Holt made his famous statement that Australia was 'all the way with LBJ' on the South Lawn of the White House in June 1966, but he had had no part in shaping it. His role was simply to record how welcome this support had been for the Johnson Administration, especially in contrast to the criticism from the British Government. But the American requests for more support continued, especially as the Indonesian-Malaysian Confrontation wound down. Johnson put pressure on the visiting Australian Treasurer, William

22 Ibid., pp. 355-6, 365.

23 Ibid., p. 364. 
McMahon, over a further increase to the Australian commitment. This led to the announcement of a decision already taken to add a third battalion to the Australian taskforce. ${ }^{24}$

The personal rapport between Johnson and Holt was not maintained by their respective successors. The Tet offensive, in which the Vietnamese communist forces failed militarily but gained a strategic victory through the impact on American public opinion, occurred soon after Gorton's accession to the prime ministership. At the height of the offensive, Gorton stated publicly that there would be no further increases in the Australian commitment. This was no more than making public what the Holt Government had decided the previous year, but it was a clear sign of the new Prime Minister's distress over the Vietnam commitment. Gorton clearly felt locked into a commitment for which he had never shared the initial enthusiasm of Menzies and Holt, but he could not see a way out. His manifest disdain for the officials in External Affairs and Defence also extended to ambassadors.

When Johnson startled the world in March 1968 with the announcement that he would not be standing for re-election, Gorton vented his anger at the lack of consultation with his Australian ally. Waller could hardly be blamed for that: even many of Johnson's closest associates knew nothing of his decision until it was publicly announced. Soon afterwards, Gorton made his first visit to the White House as prime minister. Waller later recorded that 'a more uncomfortable first meeting between two men I have never seen'. Gorton seemed torn between wanting a demonstration of presidential fellowship, akin to that enjoyed by Holt, and resenting the sense that he was being 'annexed' or 'captured' by the honours and attention that Johnson bestowed upon him. ${ }^{25}$

Nor would matters improve when Nixon was elected in November, to take office in January 1969. Soon after the election, Waller reported that he had no idea what to expect from the new regime. In the Nixon Administration's first year it introduced the policy of 'Vietnamisation', under which more of the fighting would be carried out by the South Vietnamese forces, allowing the Americans to withdraw some of their men. The American withdrawals further added to the tension in

24 Peter Edwards, A Nation at War: Australian Politics, Society and Diplomacy during the Vietnam War 1965-1975, Allen \& Unwin in association with the Australian War Memorial, Sydney, 1997, pp. 154-5.

25 James Curran, Unholy Fury: Whitlam and Nixon at War, Melbourne University Press, 2015, pp. 90-2. 
the Washington-Canberra relationship. The Australians came under domestic public pressure to begin a similar graduated withdrawal, but the Americans pressed their allies to maintain their much smaller commitments. Gorton was repeatedly embarrassed by announcements of American withdrawals on which it was obvious that Australia had not been consulted. Again Waller had to bear some of his anger, but Nixon and his National Security Adviser, Henry Kissinger, kept their decisions extremely close. Waller found access to the Nixon White House extremely difficult, and thought that William Bundy's successor in the State Department, Marshall Green, had limited influence. ${ }^{26}$

Moreover, an ambassador's effectiveness depends not only on the willingness of the host government to share information and ideas, but also on the ability of the government they represent to give clear directions in executing a coherent strategy. Particularly in the second half of his term, Waller had the misfortune to be the envoy of a tired and increasingly dysfunctional government, which was wracked by intense personal rivalries and dissolving into policy paralysis. Any government would have found it difficult to shape effective foreign and defence policies, especially to seek an honourable exit from the increasingly unpopular Vietnam commitment without prejudicing the American relationship, but it was out of the question for a government torn by the bitter rivalries between Prime Minister Gorton, Foreign Minister McMahon, and the young and ambitious Defence Minister, Malcolm Fraser.

So, despite his professional skill, Waller was a frequently uncomfortable witness to, rather than an active participant in, decision-making on the Vietnam War. Both in the escalation of the war and the beginning of the withdrawal, much of Waller's role consisted of fruitless attempts to find out what the President, first Johnson and then Nixon, had in mind. His lack of success should not be held against him; even the respective presidents' closest advisers and most senior officials were often no better informed.

26 Waller, A Diplomatic Life, p. 39. 


\section{Conclusion}

Having formed the view that his predecessor, Howard Beale, had been too long in Washington, Waller himself was glad to leave in 1970. His contemporary and former departmental head, Arthur Tange, was designated to succeed him. Although agrément had not been sought, the Tanges and the Wallers exchanged detailed correspondence about the transition. Then, in circumstances worthy of an episode of Yes, Minister, Tange was offered both his old job as Secretary of External Affairs and another headship, Secretary of Defence. The outcome of a flurry of communications was that Tange went to Defence, James Plimsoll to Washington and Waller to be Secretary of External Affairs - probably the most important appointments for each of these three outstanding public servants. ${ }^{27}$ In that sense, Waller's term in Washington was not, as one might have expected, the pinnacle of his career, but an important step towards the position that was.

Waller's term was significant, but not quite in the ways that one might have expected. He was the first career diplomat appointed to Washington, but only by default. Nevertheless, he did well enough to ensure that he was certainly not the last. Waller had a remarkably large amount of face-to-face time with Johnson, but in circumstances that meant that he had no special influence. He was there for the peak years of the Vietnam War, but he was largely a bystander as far as the major policy decisions were concerned. He was a channel for communications between those who actually made policy, often frustrated by severe limits on the consultation or even information that the Americans offered to their Australian ally. He was also a witness to the tensions in the personal relationships between Gorton and both Johnson and Nixon. Waller was the consummate Australian diplomatist, but the nature of politics and diplomacy at the time were such that his skills were not deployed as effectively or influentially as one might have expected. 
This text is taken from Australia goes to Washington: 75 years of Australian representation in the United States, edited by David Lowe, David Lee and Carl Bridge, published 2016 by ANU Press, The Australian National University, Canberra, Australia. 